\title{
A fatal case of malignant neurocysticercosis
}

\author{
Sidney Ching Liang Ong, ${ }^{1}$ Kwee Choy Koh ${ }^{2}$
}

Radiology Department, Clinical Campus, International Medical University, Seremban, Negeri Sembilan, Malaysia ${ }^{2}$ Department of Medicine, Clinical Campus, International Medical University, Seremban, Negeri Sembilan, Malaysia

\section{Correspondence to} Dr Sidney Ching Liang Ong, sidney_ong@yahoo.co.uk

Accepted 15 September 2017

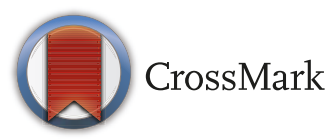

To cite: Ong SCL, Koh KC. BMJ Case Rep Published Online First: [please include Day Month Year]. doi:10.1136/bcr-2017222281

\section{DESCRIPTION}

A 43-year-old Muslim woman presented with intermittent fever, lethargy, poor appetite and weight loss for a month and altered behaviour for a week. She had a holiday trip to the provincial town of Hat Yai in South Thailand 7 months prior where she had eaten pork-free street food. On admission, she was confused, lethargic and not obeying command. There was no motor deficit.

Septic workup for bacterial and fungal infections was negative. Cerebrospinal fluid analysis showed pleocytosis with a negative tuberculosis (TB)-PCR result. IgG serology for HIV, Toxoplasma gondii and Taenia solium was negative.

Initial CT brain showed white matter hypodensities at bilateral frontoparietal regions. Several small peripherally enhancing parenchymal lesions seen on contrast-enhanced CT. These lesions were well circumscribed with no calcification or soft-tissue component. No hydrocephalus was seen.

MRI brain later revealed multiple small rim-enhancing cystic lesions in the basal ganglia, grey-white matter junctions and subarachnoid spaces. Some of these lesions are multiloculated (figure 1). None of the lesions showed restricted diffusion or blooming artefact. There was also evidence of focal subarachnoid and pachymeningeal enhancement (figure 2).

A diagnosis of neurocysticercosis (NCC) was made. Her condition improved transiently with oral albendazole and dexamethasone. She was discharged home well to complete the remaining course of albendazole. However, she presented to another hospital with signs and symptoms of meningism within 2 weeks after discharge. CT brain then showed obstructive hydrocephalus. She succumbed to her illness shortly after she was referred back to us.

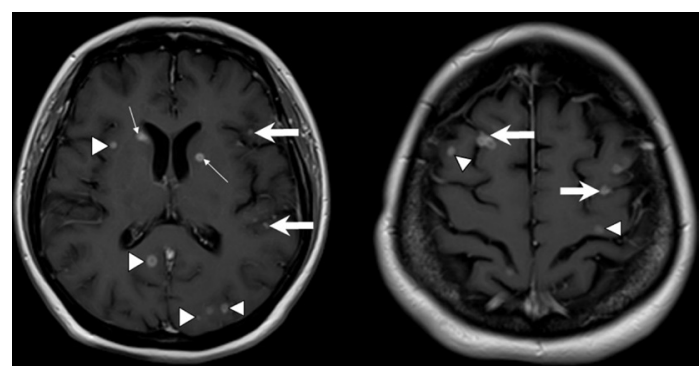

Figure 1 MRI brain in T1-weighted postgadolinium sequence showing multiple rim-enhancing lesions within the basal ganglia (thin arrows), grey-white matter junctions (arrowheads) and subarachnoid spaces (thick arrows).

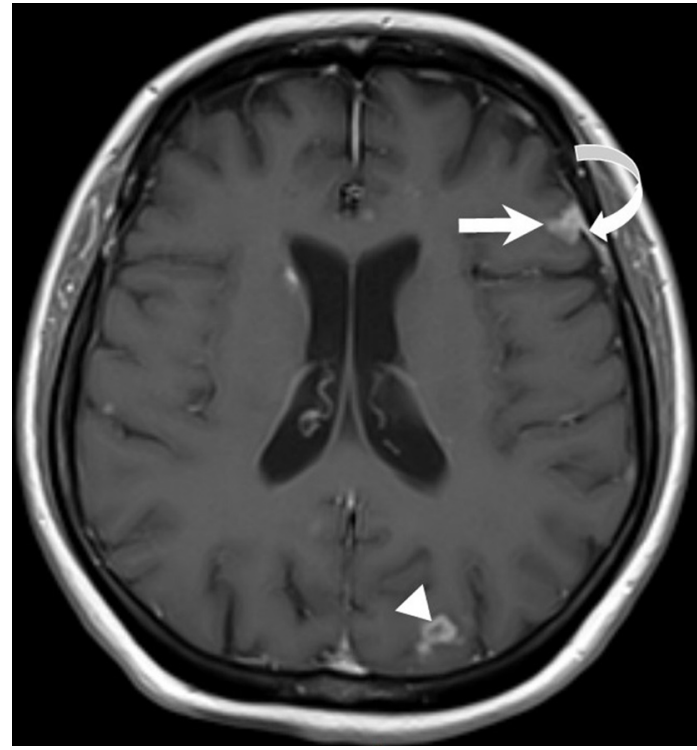

Figure 2 MRI brain in T1-weighted postgadolinium sequence showing focal enhancement in the left frontal subarachnoid space (thick arrow) indicating arachnoiditis and adjacent pachymeningeal enhancement (curved arrow). Another parenchymal rim-enhancing lesion at left parietal grey-white matter junction (arrowhead).

It is challenging to diagnose NCC, particularly when clinical and laboratory findings are inconclusive. The IgG for T. solium was negative, but it could be due to sampling prior to seroconversion. In our case, the diagnosis was only confidently made following MRI findings and clinical improvement with albendazole. Unfortunately, she succumbed to the dreaded complication of obstructive hydrocephalus despite adequate medical therapy.

NCC is the most common parasitic disease of the human central nervous system and is a leading cause of acquired epilepsy in the developing world. ${ }^{12}$ Our patient, however, did not present with seizure.

Humans acquire NCC from ingestion of infected food (most notably, pork) or faecal-oral route by individuals who are tapeworm carriers. ${ }^{12}$ In view of strict pork-free diet practices, the deceased had most likely acquired the infection via faecal-oral route.

On imaging, it is important to scrutinise the stages of the cysts (non-cystic, vesicular, colloidal vesicular, granular nodular and calcified nodular), their locations (subarachnoid cisternal, parenchymal and intraventricular) and the presence of arteritis, arachnoiditis or ventricular involvement. Arachnoiditis and ventricular involvement are often associated with obstructive hydrocephalus. A fully grown cyst up to $20 \mathrm{~mm}$ in size or a cluster of cysts (racemose) can be observed. ${ }^{2}$ 
Differential diagnoses such as tuberculomas or intracranial toxoplasmosis must be considered, especially when there is only parenchymal involvement.

Combination medical therapy (antihelminthic and corticosteroid) is usually adequate for active diseases. Surgical removal of cysts should be considered only in patients who have

\section{Learning points}

- Neurocysticercosis (NCC) is the most common parasitic disease of the human central nervous system.

- NCC can occur via direct consumption of infected pork or faecal-oral route from human carriers of tapeworm.

- On imaging, it is important to scrutinise the stages of the cysts, their locations and the presence of arteritis, arachnoiditis or ventricular involvement.

- Differential diagnoses of tuberculomas and intracranial toxoplasmosis must be considered when there is parenchymal involvement. life-threatening intracranial hypertension despite treatment with corticosteroids. Unfortunately, our patient was too ill to undergo any surgical intervention. ${ }^{13}$

Contributors SCLO: Corresponding author who provided interpretation for CT and MRI images. Obtained consent for publication from patient's next of kin (younger sister). KCK: infectious disease consultant who was directly in charge of patient's management from the beginning until death. He was instrumental in providing patient's clinical progress and management. Both authors read and approved the final manuscript.

Competing interests None declared.

Patient consent Obtained.

Provenance and peer review Not commissioned; externally peer reviewed.

(c) BMJ Publishing Group Ltd (unless otherwise stated in the text of the article) 2017. All rights reserved. No commercial use is permitted unless otherwise expressly granted.

\section{REFERENCES}

1 Del Brutto OH. Neurocysticercosis: a review. ScientificWorldJournal 2012;2012:1-8.

2 Kimura-Hayama ET, Higuera JA, Corona-Cedillo R, et al. Neurocysticercosis: radiologicpathologic correlation. Radiographics 2010;30:1705-19.

3 Proaño JV, Madrazo I, Avelar F, et al. Medical treatment for neurocysticercosis characterized by giant subarachnoid cysts. N Engl J Med 2001;345:879-85.

Copyright 2017 BMJ Publishing Group. All rights reserved. For permission to reuse any of this content visit

http://group.bmj.com/group/rights-licensing/permissions.

BMJ Case Report Fellows may re-use this article for personal use and teaching without any further permission.

Become a Fellow of BMJ Case Reports today and you can:

- Submit as many cases as you like

- Enjoy fast sympathetic peer review and rapid publication of accepted articles

- Access all the published articles

Re-use any of the published material for personal use and teaching without further permission

For information on Institutional Fellowships contact consortiasales@bmjgroup.com

Visit casereports.bmj.com for more articles like this and to become a Fellow 